\title{
EVALUASI KEBIJAKAN PROSES PEMBANGUNAN PLTN DI SEMENANJUNG MURIA KABUPATEN JEPARA JAWA TENGAH
}

\author{
Oleh \\ Qiqi Asmara \\ Dosen Universitas Muhammadiyah Jakarta \\ email: qiqiasmara@gmail.com
}

\begin{abstract}
ABSTRAK. Pokok permasalahan yang menjadi fenomena dalam penelitian ini adalah evaluasi kebijakan proses pembangunan pembangkit listrik tenaga nuklir di Semenanjung Muria Kabupaten Jepara Provinsi Jawa Tengah. Evaluasi kebijakan ini dirancang untuk dapat mendeskripsikan tahapan proses, mekanisme serta tujuan evaluasi kebijakan pembangunan dalam pelaksanaan pembangunan reaktor nuklir di Semenanjung Muria. Krisis energi nasional yang dihadapi negara Indonesia dapat diatasi dengan adanya energi alternatif yaitu pembangkit listrik tenaga nuklir. Hasil evaluasi yang dilakukan oleh BATAN menyatakan tentang kelayakan pembangunan pembangkit listrik tenaga nuklir di Semenanjung Muria, namun hal ini bertentangan dengan pendapat masyarakat yang menolak dengan tegas proses pembangunan pembangkit listrik tenaga nuklir di wilayah mereka. Hal ini yang kemudian peneliti analisa lebih lanjut dan menjadi fokus bahasan dalam penelitian ini. Penelitian ini mengunakan teori evaluasi kebijakan Dunn sebagai pisau analisa dalam menganalisis evaluasi kebijakan proses pembangunan reaktor nuklir di semenanjung muria. Adapun dimensi evaluasi kebijakan yang diteliti yaitu efektivitas, efisiensi, kecukupan, perataan, responsivitas, dan ketepatan. Penelitian ini menggunakan metode kualitatif, dengan menggunakan data primer dan data sekunder. Data primer didapatkan melalui wawancara mendalam mengenai persepsi pihak terkait mengenai kebijakan tersebut. Data sekunder yang dikumpulkan berupa kronologi kebijakan, peraturan perundangan dan berita mengenai tema penelitian. Hasil penelitian ini menunjukkan bahwa evaluasi kebijakan pembangunan pembangkit listrik tenaga nuklir di Semenanjung Muria belum berjalan dengan efektif. Hal ini dikarenakan kehawatiran masyarakat akan bahaya radiasi nuklir yang mungkin ditimbulkan dalam pengoperasian reaktor nuklir. Selain itu permasalahan yang berkaitan dengan permasalahaan politis juga berdampak pada ketidaksesuaian hasil evaluasi yang dilakukan oleh BATAN dengan kondisi yang terjadi di lapangan. Hal ini berlanjut dengan adanya era reformasi yang berdampak langsung pada berubahnya arah pembanguan dan kebijakan ketenaganukliran nasional.
\end{abstract}

Kata Kunci: Evaluasi Kebijakan, Semenanjung Muria, Energi Nuklir

ABSTRACT. The main problem that has become a phenomenon in this study is the evaluation of the policy of the process of building a nuclear power plant in the Semenanjung Muria, Jepara Regency, Central Java Province. This policy evaluation is designed to be able to describe the stages of the process, mechanism and objectives of development policy evaluation in the implementation of the construction of nuclear reactors in the Muria Peninsula. The national energy crisis facing the country of Indonesia can be overcome by the existence of alternative energy, namely nuclear power plants. The results of the evaluation conducted by BATAN stated the feasibility of building a nuclear power plant on the Semenanjung Muria, but this contradicts the opinions of the people who strongly reject the process of building a nuclear power plant in their region. This is then the researcher analyzes further and becomes the focus of discussion in this study. This study uses Dunn's policy evaluation theory as an analysis knife in analyzing the policy evaluation of the process of building a nuclear reactor on the Semenanjung Muria. The dimensions of the policy evaluation studied are effectiveness, efficiency, adequacy, leveling, responsiveness, and accuracy. This study uses qualitative methods, using primary data and secondary data. Primary data were obtained through in-depth interviews with related parties' perceptions about the policy. Secondary data collected in the form of a chronology of policies, laws and 
regulations and news about the research theme. The results of this study indicate that the evaluation of nuclear power plant development policies on the Semenanjung Muria has not been effective. This is due to public concern about the dangers of nuclear radiation that may be caused in the operation of nuclear reactors. In addition, problems related to political issues also have an impact on the discrepancy of the results of evaluations conducted by BATAN with the conditions that occur in the field. This continues with the era of reforms which has a direct impact on changing the direction of development and national nuclear policies.

\section{Keywords: Policy Evaluation, Semenanjung Muria, Nuclear Energy}

\section{PENDAHULUAN}

Salah satu faktor penting dalam menunjang kegiatan industri adalah faktor sumber daya energi. Tidak hanya bidang industri yang memerlukan ketersediaan energi yang cukup, melainkan semua kegiatan yang menyangkut kehidupan manusia. Transportasi, industri, perikanan, pertanian modern, perkantoran, pendidikan, rumah sakit, rumah tangga dan lainnya memerlukan energi, baik energi stasioner berupa tenaga listrik maupun energi non-stasioner berupa bahan bakar fosil (minyak, gas dan batubara).

Dari tahun ke tahun, sumber daya energi semakin banyak diperlukan, sedangkan sumber daya alam penghasil sumber daya energi semakin sedikit jumlahnya. Ketidakhati-hatian dan kekurangcermatan dalam merencanakan pemakaian sumber daya alam penghasil sumber daya energi akan menjadi permasalahaan yang besar apabila tidak ditemukan jalan keluar untuk menyelesaikan permasalahaan energi yang ada. Jadi, masalah sumber daya energi merupakan masalah yang harus dicari pemecahannya oleh semua negara.
Krisis energi yang melanda dunia pada tahun 1970an telah melumpuhkan perekonomian di sejumlah negara. Krisis energi dikhawatirkan akan terulang kembali pada sejumlah negara yang tidak memiliki sumber daya alam yang cukup berupa bahan bakar fosil.

Berangkat dari pengalaman tersebut, negara-negara industri maju mulai mengalihkan ketergantungan energinya dari bahan bakar fosil ke energi terbarukan. Energi terbarukan yang dimaksudkan adalah energi listrik dari hydropower berupa Pembangkit Listrik Tenaga Air (PLTA) baik yang bersumber dari air terjun maupun air bendungan, energi listrik dari panas bumi (geothermal energy), energi listrik dari laut (ocean thermal energy conversion), energi dari panas matahari (solar energy); yaitu energi listrik arus searah yang dihasilkan dari tenaga surya yang diubah menjadi tenaga listrik melalui photo voltaic cell, dan energi kekuatan angin yang berhembus kuat secara berkesinambungan melalui kincir angin. Energi terbarukan ini kebanyakan merupakan energi stasioner yang ternyata tetap tidak dapat mencukupi kebutuhan energi yang diperlukan, karena 
tenaga listrik yang dibangkitkan dari energi terbarukan sangat terbatas.

Atas dasar hal itu, maka pemanfaatan teknologi nuklir dalam bidang energi (nuclear power plan) berupa Pembangkit Listrik Tenaga Nuklir (PLTN) menjadi pilihan utama sejumlah negara industri maju.

Bahkan saat ini, PLTN juga telah menjadi sebuah keharusan yang mau tidak mau harus dibangun di beberapa negara industri maju, seperti, Korea Selatan, Taiwan dan Cina. Sedangkan negara-negara di Amerika dan Eropa sudah sejak pertengahan tahun 1950an telah memanfaatkan energi nuklir untuk pembangkit tenaga listrik. Berdasarkan data tahun 2011, Amerika Serikat memiliki 103 buah PLTN, Perancis 59 buah PLTN, Jepang 53 buah PLTN, India 14 buah PLTN, Korea Selatan 16 buah PLTN, Cina 3 buah PLTN dan Pakistan 2 buah PLTN. Perancis adalah negara terbesar yang pasokan tenaga listriknya berasal dari PLTN, yaitu $79,4 \%$ dari keseluruhan kebutuhan tenaga listriknya. (Nurlaila, 2000:62).

Tingkat kebutuhan energi di Indonesia mengalami peningkatan setiap tahunnya seiring dengan kenaikkan jumlah penduduk, perubahan pola hidup, tingkat kemakmuran masyarakat dan perubahan pada beberapa aspek kehidupan yang lain. Bagi Indonesia, fenomena krisis energi yang sedang melanda saat ini setidaknya telah menyadarkan bahwa sudah menjadi satu keharusan untuk selalu mengikuti kemajuan dan perkembangan ilmu pengetahuan dan teknologi yang melaju sangat cepat. Dimana kecenderungan masyarakat dunia sekarang lebih banyak menggunakan ilmu pengetahuan dan teknologi dalam memperoleh energi. Salah satunya dengan pemanfaatan pengembangan nuklir sebagai sumber energi baru. Hal ini sejalan dengan referensi yang penulis dapat sebagai berikut:

Kebutuhan energi selalu meningkat dari tahun ke tahun, terutama di Indonesia, data yang diperoleh dari Departemen Pertambangan dan Energi untuk 10 tahun menjelang berakhirnya abad 20 yang lalu yaitu: (1) Minyak bumi 508,4 juta barel $(1973 / 1974) ; 517,6$ juta barel (1983/1984); 553,0 juta barel (1990/1991), (2) Gas Bumi 186,1 ribu Mcf (1973/1974); 1.228,2 ribu Mcf (1983/1984); 2.206,9 ribu Mcf, (3) Batu Bara 145,8 ribu ton (1973/1974); 614,7 ribu ton (1983/1984); 11.211,6 ribu ton (1990/1991), (4) LNG 226,2 juta MMBTU (1978/1979); 569,3 juta MMBTU (1983/1984); $1.142,0$ juta MMBTU (1990/1991). Menurut laju pertumbuhan konsumsi listrik di Indonesia selama PELITA V yang lalu menunjukan angka luar biasa, yaitu sekitar $17,5 \%$ per tahun. Laju pertumbuhan konsumsi listrik yang besartersebut sebagai akibat dari keinginan bangsa Indonesia untuk mengubah nasibnya dari keadaan negara berkembang menuju ke arah negara industri, dengan harapan agar tingkat kehidupan kita akan lebih baik lagi (Wisnu Arya Wardhana, 2009:139-140).

Adapun gambaran cadangan sumber daya energi kita dibandingkan dengan cadangan dunia yang ada pada tahun 2000 adalah:

\begin{tabular}{cccc}
\hline No & $\begin{array}{c}\text { Sumber } \\
\text { Daya Energi }\end{array}$ & Indonesia & $\begin{array}{c}\% \text { Potensi } \\
\text { Dunia }\end{array}$ \\
\hline 1 & Minyak Bumi & $\begin{array}{c}321 \text { miliar } \\
\text { barel }\end{array}$ & $1,2 \%$ \\
2 & Gas Bumi & 507 TSCF & $3,3 \%$ \\
3 & Batubara & 50 miliar ton & $3,0 \%$ \\
4 & Panas Bumi & $27 \mathrm{MW}$ & $40 \%$ \\
5 & Tenaga Air & $75 \mathrm{MW}$ & $0,02 \%$ \\
\hline
\end{tabular}


Tahun 2002, cadangan minyak bumi sekitar 5 miliar barel cadangan gas bumi sekitar 90 TSCF cadangan terbukti batubara sekitar 5 miliar ton apabila tingkat produksi tetap seperti tingkat tahun 2002 dan tidak ditemukan cadangan terbukti baru, maka cadangan minyak bumi diperkirakan akan habis dalam waktu kurang dari 10 tahun. Sedangkan gas bumi akan habis dalam waktu 30 tahun dan batubara akan habis sekitar 50 tahun (Wisnu Arya Wardhana, 2009:142).

Tingkat kebutuhan energi di Indonesia pun mengalami peningkatan setiap tahunnya seiring dengan kenaikkan jumlah penduduk, perubahan pola hidup, tingkat kemakmuran masyarakat dan perubahan pada beberapa aspek kehidupan. Bagi Indonesia, fenomena krisis energi yang sedang melanda saat ini setidaknya telah menyadarkan bahwa sudah menjadi satu keharusan untuk selalu mengikuti kemajuan dan perkembangan ilmu pengetahuan dan teknologi yang melaju sangat cepat. Dimana kecenderungan masyarakat dunia sekarang lebih banyak menggunakan ilmu pengetahuan dan teknologi dalam memperoleh energi. Salah satunya dengan pemanfaatan pengembangan nuklir sebagai sumber energi baru

\section{METODE PENELITIAN}

Penelitian ini adalah penelitian evaluasi yang merupakan ex-post, evaluation atau disebutkan oleh Dunn (2003:612) sebagai evaluasi sumatif.
Dalam penelitian ini pendekatan yang dipilih adalah evaluasi formal yaitu merupakan pendekatan yang menggunakan metode deskriptif untuk mendapatkan informasi yang valid dan dapat dipercaya, tentang hasil-hasil kebijakan. Namun demikian evaluasi dilakukan atas dasar tujuan program yang telah diumumkan secara formal oleh pembuat kebijakan dan administrator program. Asumsi utama dari evaluasi formal adalah tujuan dan target dimumkan secara formal, merupakan ukuran yang tepat untuk manfaat atau nilai kebijakan program.

Penelitian ini memiliki: pertama, Data Primer diperoleh dari hasil observasi lapangan dan wawancara mendalam dengan seluruh informan. Kedua, Data Sekunder berupa Laporan hasil evaluasi yang didokumentasikan oleh masingmasing evaluator, yaitu: Kementerian Riset dan Teknologi, Badan Tenaga Nuklir Nasional, Badan Pengawas Tenaga Nuklir, Pengurus Cabang Nahdatul Ulama Jepara, Environment Parliement Watch (EPW) Jakarta, Bupati Kabupaten Jepara, Pengamat Kelistrikan. Termasuk didalamnya Peraturan atau kebijakan yang terkait dengan Pembangkit Listrik Tenaga Nuklir, yaitu: (1) Undang-Undang Nomor 10 tahun 1997 Tentang Ketenaganukliran, (2) Peraturan Presiden Republik Indonesia Nomor 5 Tahun 2006 Tentang Kebijakan Energi Nasional, (3) Undang-Undang Nomor 17 Tahun 2007 tentang Rencana Pembangunan Jangka 
Panjang Nasional (RPJPN) 2005 - 2025, (4) Blueprint Pengelolaan Energi Nasional 2005 -2025, (5) Blueprint Rencana Umum Ketenagalistrikan Nasional 2005 - 2025, (6) Peraturan Pemerintah Republik Indonesia Nomor 43 Tahun 2006 Tentang Perizinan Reaktor Nuklir, (7) Peraturan Pemerintah Republik Indonesia Nomor 79 Tahun 2014 Tentang Kebijakan Energi Nasional.

Dalam Teknik Pengumpulan dan Pengolahan Data, dilakukan Pendekatan wawancara yang digunakan dalam penelitian ini menggunakan tiga jenis pendekatan wawancara secara kualitatif, sejalan dengan rumusan Moleong (2007:184):

Wawancara percakapan informal, pendekatan pedoman wawancara umum dan wawancara terbuka yang dilakukan" dengan semua informan. (1) Wawancara percakapan informal, dilakukan untuk menggali informasi secara spontan dalam alur pembicaraan alami pada kegiatan mendalami partisipasi selama observasi pada kondisi informan memiliki waktu yang cukup luang untuk menggambarkan informasi secara sistematis, (2). pendekatan pedoman wawancara umum, untuk mengantisipasi keterbatasan waktu pada wawancara informal maka dibuat pedoman umum wawancara yang memuat segala pertanyaan yang diperlukan untuk ditanyakan kepada informan, pedoman ini memberikan panduan bahwa pertanyaan esensial saja yang harus ditanyakan guna memecahkan masalah penelitian. dan wawancara terbuka yang dibakukan, wawancara jenis ini dilakukan dengan mengajukan seperangkat pertanyaan yang disusun dengan seksama, bertujuan untuk mengambil data setiap informan melalui urutan yang sama dan menanyai setiap responden dengan pertanyaan yang sama dengan katakata yang esensinya sama, hal ini dilakukan untuk memperkecil variasi pertanyaan yang ditujukan kepada informan yang diwawancarai.

Informan dalam penelitian ini adalah para implementator kebijakan, serta para pemangku kepentingan yang terlibat dalam kebijakan proses pembangunan PLTN. Adapun para informan tersebut adalah: (1) Kementerian Riset dan Teknologi. (Juhaidi Ritongga), (2) Badan Tenaga Nuklir Nasional. (Hudi Hastowo), (3) Badan Pengawas Tenaga Nuklir.(Jupiter Sitorus Pane), (4) Pengurus Cabang Nahdatul Ulama (NU) Kab.Jepara. (Asyhari Syamsuri), (5) Environment Parliement Watch (EPW) Jakarta. (Evita Nursanty), (6) Bupati Jepara, Pengamat Kelistrikan. (Hendro Martojo), (7) Masyarakat / Pengamat. (Abdul Wahid).

Tahap pengumpulan dan analisis data. Teknik analisis data kualitatif yang digunakan dalam penelitian ini mengacu pada teknik analisis yang dikemukakan Miles dan Huberman (1992:18) bahwa:

Proses analisis data kualitatif terdiri dari tiga alur kegiatan utama yang terjadi secara bersamaan, yaitu: reduksi data, penyajian data, penarikan kesimpulan atau verifikasi." Pertama, reduksi data, sebagai proses pemilihan, pemusatan fokus pada penyederhanaan dan abstraksi serta transformasi data kasar yang muncul dari catatan-catatan tertulis di lapangan. Kedua, penyajian data, dimaknai sebagai sekumpulan 
informasi tersusun yang memberi kemungkinan adanya penarikan kesimpulan dan pengambilan tindakan. Terdapat variasi bentuk yang dapat digunakan dalam penyajian, antara lain; matriks, grafik, jaringan, serta bagan-bagan. Ketiga, menarik kesimpulan/verifikasi, merupakan kegiatan analisis yang amat penting sebagai suatu kesimpulan penelitian yang menjadi tujuan akhir. Pada dasarnya penelitian memperlakukan data sebagai temuan awal yang masih terbuka terhadap perubahanperubahan. Kesimpulan akhir adalah pada saat tahap pengumpulan data telah selesai dilakukan.

\section{HASIL DAN PEMBAHASAN}

\section{Tahap Pelaksanaan Kebijakan Proses Pembangunan PLTN di Semenanjung Muria Kabupaten Jepara Provinsi Jawa Tengah}

Kebijakan energi nasional yang ditandatangani oleh presiden pada tanggal 25 Januari 2006. Dalam tahun 2007, Dewan Perwakilan Rakyat Republik Indonesia telah mengesahkan Undang Undang No 17 tahun 2007 tentang Perencanaan Pembangunan Nasional 2015-2019 dan Undang-undang No. 30 tahun 2007 tentang Energi (yang dipandang sebagai "perekat" beberapa Undang-undang mengenai pelbagai jenis energi seperti minyak dan gas bumi, ketenagalistrikan, panas bumi, ketenaganukliran dan pertambangan batubara), dan menyebutkan bahwa energi listrik yang berasal dari nuklir harus sudah mulai dipergunakan pada kurun waktu 2015-2019.
Dari sisi teknis, tenaga nuklir pada tahap penentuan tapak pada studi kelayakan tapak yang dilakukan Badan Tenaga Nuklir Nasional (BATAN) telah mencari lokasi yang dinilai tepat untuk dibangun Pembangkit Listrik Tenaga Nuklir. Dari sekitar 14 (empat belas) tapak yang ditelusuri di seluruh wilayah Indonesia, akhirnya ditentukan sekitar 5 (lima) lokasi yang dinilai layak untuk dibangun Pembangkit Listrik Tenaga Nuklir. Namun, kemudian berdasarkan hasil kajian mendalam yang dibantu oleh konsultan NEWJEC pada tahun 1996 untuk melaksanakan pekerjaan tentang pemilihan dan evaluasi tapak PLTN di Indonesia ditetapkanlah satu wilayah yang paling layak dibangun, yaitu di Semenanjung Muria, Kabupaten Jepara, Jawa Tengah.

Pertimbangannya pemilihan lokasi di Semenanjung Muria, Kabupaten Jepara, Provinsi Jawa Tengah berdasarkan hasil kajian menyeluruh adalah lokasi tersebut berdekatan dengan gunung Muria yang juga merupakan gunung api yang sudah "mati", dan berdekatan dengan laut karena tentunya sebuah Pembangkit Listrik Tenaga Nuklir ini perlu banyak air untuk prosesnya serta dekat dengan wilayah pasar yang membutuhkan energi listrik yaitu pulau Jawa. Berdasarkan pertimbangan tersebut pemerintah menetapkan gunung Muria sebagai lokasi pembangunan Pembangkit Listrik Tenaga Nuklir. 
Berangkat dari berbagai dasar kebijakan ini, kemudian diterjemahkan oleh Kementerian Riset dan Teknologi menjadi dua hal yang penting. Pertama, bahwa PLTN pertama akan dioperasikan Indonesia pada tahun 2016/2017. Kedua, persiapan-persiapan berkenaan dengan sosialisasi kepada masyarakat harus segera dilakukan. Untuk keperluan sosialisasi itulah kemudian Kementerian Riset dan Teknologi mengusulkan sejumlah kegiatan melalui APBN yang diajukan melalui Kementerian Keuangan, Bappenas, dan disetujui DPR RI.

\section{Evaluasi Kebijakan Proses \\ Pembangunan Reaktor Nuklir Di Semenanjung Muria, Kabupaten Jepara, Provinsi Jawa Tengah}

Hasil kerja dari para evaluator implementasi kebijakan proses pembangunan PLTN Semenanjung Muria. Adapun para evaluator yang dimaksud adalah Kementerian Riset dan Teknologi, Badan Tenaga Nuklir Nasional, Badan Pengawas Tenaga Nuklir, Pengurus Cabang Nahdatul Ulama Jepara, Environment Parliement Watch Jakarta, Bupati Kabupaten Jepara, Pengamat Kelistrikan, Masyarakat/Pengamat.

Atas dasar ini maka penelitian evaluasi ini terfokus pada pengamatan atau evaluasi yang dilakukan oleh evaluator (lembaga atau instansi yang melakukan evaluasi) terhadap kebijakan proses pembangunan PLTN di Semenanjung Muria. Adapun sebagaimana telah diuraikan pada bagian teoritik, pengamatan evaluator akan dicermati dari dimensi efektivitas, efisiensi, perataan, dan responsivitas.

\section{a) Dimensi Efektivitas}

Efektivitas dalam penelitian ini dipahami sebagai sebuah upaya untuk memperoleh jawaban

berkenaan dengaan apakah suatu alternatif mencapai hasil (akibat) yang diharapkan, atau mencapai tujuan dari diadakannya tindakan, selaras apa yang dikemukan oleh Dunn (2003: 429), Efektivitas yang secara dekat berhubungan dengan rasionalitas teknis, selalu diukur dari unit produk atau layanan atau nilai moneternya.

Jika generator nuklir menghasilkan lebih banyak energi dibandingkan alat bertenaga matahari, maka yang tersebut pertama dinilai sebagai lebih efektif, karena generator nuklir memberikan hasil yang lebih dihargai. Begitu juga, kebijakan kesehatan yang efektif adalah kebijakan penyediaan pelayanan kesehatan yang lebih bermutu, dengan asumsi bahwa kualitas pelayanan kesehatan adalah hasil yang bernilai (tujuan). Dari hasil penelitian ini tujuan yang ingin dicapai dari evaluasi kebijakan pembangunan pembangkit listrik tenaga nuklir, menunjukan adanya efektivitas energi nuklir dibandingkan dengan energi alternatif lainnya dalam mengatasi permasalahan krisis energi nasional (Hudi Hastowo, 12 Juli 2013). 


\section{b) Dimensi Efisiensi}

Efisiensi (efficiency) menurut Dunn (2003:430) berkenaan dengan jumlah usaha yang diperlukan untuk menghasilkan tingkat efektivitas tertentu. Efisiensi yang sinonim dengan rasionalitas ekonomi adalah merupakan hubungan antara efektivitas dan usaha, yang terakhir umumnya diukur dari ongkos moneter. Efisiensi biasanya ditentukan melalui perhitungan biaya per unit produk atau layanan (misalnya, dolar per gallon irigasi air atau 50 pemeriksaan medis per per $\$$ 1000). Kebijakan yang mencapai efektivitas tertinggi dengan biaya terkecil dinamakan efesien. Hasil wawancara dengan Hudi Hastowo yang menyatakan bahwa:

Daya sebuah PLTN berkisar antara 40 Mwe sampai mencapai 2000 MWe, dan untuk PLTN yang dibangun di Semenanjung Muria mempunyai sebaran daya dari 600 MWe sampai 1200 MWe. Sampai tahun 2010 terdapat 443 PLTN yang beroperasi di dunia, yang secara keseluruhan menghasilkan daya sekitar 1/6 dari energi listrik dunia. Biaya PLTN termasuk yang paling rendah, apalagi sejak perkembangan kenaikan harga energi internasional pada tahun 2010 sampai dengan saat ini. Penggunaan PLTN di Semenanjung Muria adalah guna memenuhi permintaan beban dasar sistem listrik Jawa-Madura-Bali akan menurunkan biaya total pasokan listrik dalam sistem tersebut. (Hudi Hastowo, 12 Juli 2013).

Kinerja pengoperasian PLTN di dunia dalam periode 1991-2013 memperlihatkan keunggulannya.
Selanjutnya dinyatakan bahwa di Jepang, desain PLTN dibangun anti gempa sehingga mampu beroperasi dan memasok listrik kala gempa dasyat melanda sekitar musim dingin 1995. Lain halnya dengan Korea Selatan, pengembangan PLTN mampu meningkatkan pendapatan per kapita masyarakatnya, dari semula 400 dolar AS/tahun pada 1970 menjadi 10.000 dolar AS/tahun pada 2000.

Kiranya evaluasi pembangunan PLTN di Semenanjung Muria secara keseluruhan berdasarkan dimensi efektivitas dalam penelitian ini, dapat dikatakan dapat berjalan dengan efektif dan dapat mengatasi krisis energi nasional yang melanda bangsa Indoensia bila diselesaikan dengan penuh dedikasi tinggi dan perencanaan yang matang, untuk meminimalisir resiko kemungkinan terjadinya musibah yang dapat berdampak buruk bagi umat manusia khususnya yang ada di wilayah Semenanjung Muria.

\section{c) Dimensi Kesamaan}

Kriteria kesamaan (equity) erat berhubungan dengan rasionalitas legal dan sosial dan menunjukan pada distribusi akibat dan usaha antara kelompokkelompok yang berbeda dalam masyarakat. Kebijakan yang berorientasi pada perataan adalah kebijakan yang akibatnya (misalnya, unit pelayanan atau manfaat moneter) atau usaha (misalnya, biaya moneter) secara adil didistribusikan (Dunn, 2003: 434). 
Pemerataan dalam konteks kebijakan proses pembangunan PLTN Semenanjung Muria diinterprestasikan sebagai keuntungan atau kerugian yang diterima oleh masyarakat Jepara secara khusus atau masyarakat Indonesia pada umumnya. Dengan demikian, pemerataan dalam konteks penelitian ini diinterprestasikan sebagai efek kepuasan politik dari pemerintah terhadap pencapaian implementasi kebijakan.

Sebagian besar para pakar ahli sumberdaya energi maupun responden menyatakan setuju agar kebijakan pembangunan PLTN segera ditindaklanjuti, sehingga terwujud kebijakan go nuclear. Namun pelaksanaannya harus hati-hati dan didukung dengan mengintensifkan kegiatan sosialisasi pada masyarakat luas. Penguasaan teknologi keselamatan dan peningkatan kemampuan sumber daya manusia perlu mendapat perhatian yang sungguhsungguh, agar pembangunan dan pengoperasian PLTN berlangsung secara aman. Hal yang lebih penting dari semua ini adalah komitmen pemerintah terhadap pembangunan PLTN.

Hal ini disampaikan pandangan dari: (1) Pengurus Cabang Nahdatul Ulama (PCNU) Jepara. Asyhari Syamsuri, Pada Tanggal 10 Juli 2013), (2) Bupati Kabupaten Jepara, Periode 2002 - 2012. (Hendro Martojo, Pada Tanggal 05 September 2012), (3) informan dari Kementerian Riset dan Teknologi. (Juhaidi Ritongga, Pada Tanggal 09 Juli 2013), (4)
Narasumber dari BATAN. (Abdul Wahid, Pada Tanggal 13 Juli 2013).

\section{d) Dimensi Responsivitas}

Dimensi responsivitas (responsives) berkenaan dengan seberapa jauh suatu kebijakan dapat memuaskan kebutuhan, prefensi, atau nilai kelompok-kelompok masyarakat tertentu. Berdasarkan masukan, kritik serta saran yang masuk ke pemerinta memang beraneka ragam; ada yang sangat setuju, ragu-ragu ataupun menolak dengan tegas.

Hal ini dikarenakan adanya permasalahaan yang kemudian menjadi kendala dalam menerapkan teknologi nuklir sebagai energi alternatif di Indonesia. Adapun keterangan informan (Hardiyansyah, 2011:46) sebagai berikut:

Dari laporan evaluasi yang disampaikan oleh tim kami memang akan sulit untuk melanjutkan proses pembangunan reaktor nuklir. Hal ini tentunya dikarenakan respon masyarakat dan para pemangku kepentingan yang terlibat dalam kebijakan ini. Hal ini seharusnya memang bisa diantisipasi sejak awal oleh para ahli dalam melakukan studi pendahuluan dari mulai aktivitas penentuan tapak proyek hingga menetapkan Muria sebagai lokasi paling tepat dengan memperhatikan aspek sosial budaya yang ada di masyarakat agar dikemudian hari tidak menimbulkan reaksi penolakan dari masayarakat. Namun berdasarkan hasil evaluasi yang dilakukan oleh tim menunjukan penolakan yang sangat beragam. Hal ini tentunya harus dapat diatasi oleh para pemangku kebijakan yang ada. 


\section{KESIMPULAN}

Pelaksanaan evaluasi kebijakan proses pembangunan pembangkit listrik tenaga nuklir di Semenanjung Muria Kabupaten Jepara Provinsi Jawa Tengah yang dilakukan oleh para evaluator dengan dimensi efektivitas, efisiensi, kecukupan, perataan, responsivitas, dan ketepatan, ternyata sangat ditentukan oleh tujuan dari pelaksanan evaluasi kebijakan itu sendiri dengan menggunakan ukuranukuran untung rugi, kepuasan, manfaat dalam perspektif politik.

Berdasarkan evaluasi kebijakan proses pembangunan pembangkit listrik tenaga nuklir di Semenanjung Muria Kabupaten Jepara Provinsi Jawa Tengah dapat disimpulkan bahwa:

1. Dimensi efektifivitas, efesiensi dan kecukupan; unggul dalam perhitungan ratio biaya-manfaat merata dan laba dibandingkan alternatif pembangkit listrik lainnya, tetapi kebijakan pembangunan PLTN Semenanjung Muria ditolak oleh masyarakat karena dianggap belum diperlukan oleh masyarakat setempat, salahsatu alasannya karena masih tersedianya energi alternatif lainnya.

2. Dimensi kesamaan atau perataan, kebijakan pembangunan PLTN tidak berorientasi pada perataan atau kesamaan yang akibatnya atau usaha secara adil didistribusikan.. Kunci dari perataan yaitu keadilan atau kewajaran. Pertanyaan menyangkut perataan, kewajaran, dan keadilan bersifat politis cara-cara tersebut tidak dapat menggantikan proses politik, berarti cara-cara di atas tidak dapat dijadikan patokan untuk penilaian dalam dimensi perataan. Bahwa titik berat pada aspek legal dan aspek sosial sangat penting, hal ini dikarenakan untuk mengetahui persepsi, harapan, dan keinginan masyarakat atas segala bentuk rencana pembangunan yang ada dapat tergali dengan memahami kondisi sosial budaya yang ada di masyarakat sekitar lokasi pembangunan PLTN di Semanjung Muria.

3. Dari dimensi responsivitas dalam evaluasi kebijakan proses pembangunan PLTN menunjukan bahwa masyarakat di sekitar Semenanjung Muria tidak menyetujui kebijakan pembangunan PLTN, walaupun pemerintah sudah berupaya melakukan sosialisasi terhadap kebijakan tersebut. Pemerintah tidak pro aktif mengajak masyarakat turut berpartisipasi dalam memikirkan halhal yang penting khususnya rencana pembangunan PLTN di Semenanjung Muria. Dari dimensi responsivitas ini dapat dilihat bahwa dimensi-dimensi lainnya, efektivitas, esfesiensi, kecukupan, kesamaan atau perataan, masih gagal jika belum menanggapi kebutuhan aktual dari masyarakat yang semestinya diuntungkan dari adanya suatu kebijakan 
pembangunan pembangkit listrik

tenaga nuklir di Semenanjung Muria.

Berdasarkan kesimpulan penelitan ini, maka temuan dalam penelitian ini adalah Resposivitas merupakan faktor determinan dalam evaluasi kebijakan untuk pemenuhan kebutuhan masyarakat, oleh karena itu diperlukan partisipasi dari masyarakat secara langsung maupun tidak langsung dengan tidak serta merta mengimplementasikan kebijakan tersebut, sedangkan kebijakan tersebut memerlukan waktu yang panjang dalam implementasinya untuk itu diperlukan konsistensi dari pemerintah.

\section{DAFTAR PUSTAKA}

Dunn, William N. 2000. Public Policy Analysis : An Introduction. Edisi ke-2. Englewood Cliffs, New Jersey: Prentice-Hall, Inc., A Simon \& Schuster Company. Yogyakarta: Terjemahan dari: Gadjah Mada University Press.

Dunn, William N. 2003. Pengantar Analisis Kebijakan Publik. Edisi Kedua. Gadjah Mada University Press.

Hardiyansyah. 2011. Kualitas Pelayanan Publik. Yogyakarta: Gava Media.

Moleong, L.J. 2007. Metodelogi Penelitian Kualitatif (Edisi Revisi). Bandung. Remaja Rosdakarya.

Miles dan Hubeman. 1992. Analisis Data Kualitatif. Jakarta: UI Press.

Nurlaila. 2000. Analisis Kinerja Operasi Pembangkit Listrik Tenaga Nuklir Tipe LWR di Jepang. Jurnal Pengembangan Energi Nuklir Vol.2 No.1. BATAN.

Peraturan Presiden Republik Indonesia
Nomor 5 Tahun 2006 Tentang Kebijakan Energi Nasional.

Peraturan Pemerintah Republik Indonesia Nomor 43 Tahun 2006 Tentang Perizinan Reaktor Nuklir.

Peraturan Pemerintah Republik Indonesia Nomor 79 Tahun 2014 Tentang Kebijakan Energi Nasional.

Undang-Undang Republik Indonesia Nomor 17 Tahun 2007 Tentang Rencana Pembangunan Jangka Panjang Nasional Tahun 2005 2025.

Undang-Undang Republik Indonesia Nomor 10 Tahun 1997 Tentang Ketenaganukliran.

Undang-Undang Republik Indonesia Nomor 30 Tahun 2007 Tentang Energi.

Undang-Undang Republik Indonesia Nomor 30 Tahun 2009 Tentang Ketenagalistrikan.

Wardhana, Wisnu Arya, 2009, Al Qur'an dan Energi Nuklir, Pustaka Pelajar, Yogyakarta. 